\title{
The Effect of Sustainable Palm Oil Certification on Export and Downstream Industry Development (Indonesia-Malaysia Case)
}

\author{
Prisilia Adinda Maretna ${ }^{1}$, Heti Mulyati ${ }^{2}$, Eko Ruddy Cahyadi ${ }^{3}$, Azmawani Abd Rahman ${ }^{4}$ \\ \{prisiliadinda.22@gmail.com ${ }^{1}$, heti@apps.ipb.ac.id ${ }^{2}$, ekocahyadi@apps.ipb.ac.id ${ }^{3}$ \} \\ Department of Management, Faculty of Economics and Management, IPB University, Bogor, \\ Indonesia ${ }^{1,2,3}$ \\ Department of Management, Faculty of Economics and Management, University of Putra Malaysia, \\ Selangor, Malaysia ${ }^{4}$
}

\begin{abstract}
Palm oil plantations have been long associated with the unsustainability issue. The debate brought global leaders to establish the Roundtable on Sustainable Palm Oil (RSPO) in 2004 to set the sustainable palm oil standards. Unfortunately, palm oil remains questioned or partially banned especially in the sustainability-aware countries. This paper aims to determine the role of RSPO participation in the company's decision to export and develop palm oil downstream industry. Secondary data from 18 Indonesian and 32 Malaysian palm oil companies' annual reports are employed and analyzed using binary logistic regression. This study found that RSPO-certified and larger firms are more likely to be exporters. Contrarily, the RSPO certificate was found to be insignificant in affecting downstream development in this study. It can be concluded that the RSPO certificate is still beneficial to support palm oil export, especially in maintaining the company's good image towards its sustainability initiative.
\end{abstract}

Keywords: downstream industry, export decision, palm oil, RSPO certification, sustainability

\section{Introduction}

Nowadays, oil palm can be found in a broad line of products. It is widely used in food (oils and fats), personal care products (oleochemicals), and currently being used as alternative energy generated from biomass [1] [2] [3]. Oil palm was known for its high productivity (about five to ten times more oil yield per hectare) compared to other oil crops (rapeseed, soybean, and sunflower) [4]. Oil palm's global demand was around 90\% supplied from Southeast Asia, especially Indonesia and Malaysia.

Palm oil has a great contribution to economic development in its host country. In Indonesia's case, palm oil represents $17 \%$ of total agricultural 
revenues, making it the most important agricultural product of Indonesia [5]. Meanwhile, palm oil is considered a source of export revenue and a key contributor to gross domestic product (GDP) in Malaysia [6]. Besides, palm oil industries also generate the creation of jobs, entrepreneurship opportunities through plasma schemes [5], infrastructure development, and rural poverty reduction [7] as well as poverty alleviation (basic, physical, financial) of market-oriented livelihood [8]. On the other hand, palm oil plantation also accused as the biggest contributor toward environmental degradation [2], tropical deforestation [3] [9], greenhouse gas (GHG) emissions [10], declining quality of soil and water [11], and more negative impacts toward health issues and social problems as well [5] [12] [13].

As the sustainability awareness becomes a public agenda, many campaigns to replace the use of oil palm with a more sustainable oil crop, cultivated in nontropical areas, have been recommended [3]. To encounter the accusation, Indonesia and Malaysia are now focusing on sustaining their palm oil production activity. One of the solutions to keep this controversial commodity trade competitive and secure is obtaining sustainable certification (Roundtable on Sustainable Palm Oil or RSPO and International Sustainability and Carbon Certification or ISCC for voluntary-based certification, Malaysian Sustainable Palm Oil or MSPO and Indonesia Sustainable Palm Oil or ISPO for government-led mandatory national certification) [7] [14].

Among the sustainability certification mentioned above, RSPO is the first established certification scheme. In Indonesia, the first RSPO certificate issued in 2009 [15] while the RSPO certificate in Malaysia was first issued in 2008. Unfortunately, RSPO focused more on certifying large-scale industry, seen from the cost of certification which sometimes not affordable for smallholders [16] without affiliation with certified millers/companies/NGOs. RSPO certification is required mainly for palm oil companies who are willing to export their palm oil to the European Union (EU) and the United States (US) market [17] [14]. The implementation of RSPO will convince end-consumers that the products they consumed are certified sustainable palm oil because only palm oil is produced from certified land which has been audited against RSPO principles and criteria standards allowed to be used [18].

Unfortunately, it is found that only $48 \%$ of the total Certified Sustainable Palm Oil (CSPO) was sold in 2015 [13], which increased 3\% from the previous year [19]. The low uptake is also associated with the unbalanced revenue from the premium price of CSPO. Moreover, it observed that getting RSPO-certified resulted Malaysian growers in a loss amounting to RM 758 million annually which equivalent to $4.3 \%$ of the government's expenditure on healthcare in 
2014 [19]. Moreover, activities and travels needed in auditing growers have created an additional carbon footprint.

This research intends to explore the effectiveness of RSPO certification through a different perspective, the effect on the export decision. It is long known that the RSPO was a European-driven initiative of the World Wide Fund for Nature (WWF) and Unilever which connect the Southern production and Northern consumption of oil palm [20]. Therefore, having this certificate would bring some impacts on palm oil's trade. The relation was re-confirmed by OECD-FAO stated that certification schemes, labeling, environment legislation would affect palm supply and purchases by importer countries [21]. Besides, the low uptake of CSPO also brought producers to look after new market opportunities, domestic downstream industry. The practical relationship between RSPO and domestic downstream development would give a new insight into a better understanding of RSPO in producer countries.

\section{Literature Review}

\subsection{Sustainable Supply Chain}

Within a broader insight, to ensure that the activities are sustainable, practitioners are concerned about sustaining the entire supply chain. It means that sustainable actions are employed from the process of obtaining raw materials until the finished products reach the end-users. In terms of environmental sustainability, a new stream known as green supply chain management has arisen [22]. It is focused on developing processes that will lead to businesses becoming completely sustainable in the future. Promoting social and economic sustainability are encouraged as well to ensure that the businesses provide a good social condition for workers while maximizing the organizations' profitability.

In terms of the palm oil supply chain, sustainability covers the 3Ps: profit, planet, people. While profit is considered as the main concern of companies' stakeholders, the remaining planet and people were mostly debated by special interest groups, such as NGOs [22]. This matter resulting in companies to get sustainability certification to ensure sustainability along the supply chain. Among proposed schemes, RSPO, ISCC, ISPO, and MSPO are commonly used [13]. RSPO and ISCC are voluntary while ISPO and MSPO are government-led mandatory national schemes. In general terms, ISCC is addressed a larger share of the environmental objectives of EU and UN 
instruments, RSPO is more socially-objectives driven, MSPO in an intermediate state while ISPO generally addressed less EU and UN instruments.

Previous studies revealed the common drivers of sustainable supply chain implementation. It is categorized into internal and external drivers [22]. Internal drivers consist of people issues, strategic issues, and functional issues while external drivers come from the government, competitors, customers, suppliers, investors, and NGOs. It is argued that initiatives to adopt green supply chain management (GSCM) in Malaysian manufacturers are mostly driven by external pressures, such as regulation and marketing/customer [23]. The decision to adopt GSCM is also influenced by management commitment and industry competition. Then it confirmed that consumer' environmental knowledge and awareness does significantly influence their intention to purchase a green vehicle [24].

\subsection{Roundtable on Sustainable Palm Oil (RSPO) Certification}

Established in 2004, RSPO certification is a non-profit organization that unites stakeholders from the palm oil industry (producers, processors or traders, consumer goods manufacturers, retailers, banks/investors, and environmentalsocial NGOs to develop and implement global standards for sustainable palm oil. Up until now, RSPO reports on their website that 4576 entities already join RSPO membership and RSPO-certified palm oil accounts for 19\% (15.19 million tonnes) globally, which mainly comes from Indonesia (51\%) and Malaysia (42\%). Implementation of RSPO claimed to deliver some benefits in the area of operations, community relations, staff and labor, revenues and market access, and access to capital as well [25].

Becoming a must-be-fulfilled standard by exporters targeting the EU market, RSPO's effectiveness in delivering sustainable palm oil has been long questioned. Some researchers have investigated the effect of RSPO. One declared that there is no significant difference in operational profitability between Malaysian exporters and non-exporters due to sustainable certification [26]. But this certification is indeed required to gain trust and a good image towards the environment. Additionally, the researcher explored the effect of RSPO and/or MSPO toward financial profitability and found that profitability of a firm (reflected by return on asset) with a sustainability certification is $2 \%$ higher than those without it [27]. Another study found that RSPO and MSPO have no significant effect on firm performance and these two sustainability certifications were not in conflict with one another [28].

Meanwhile in Indonesia, a researcher revealed that RSPO certification affected the economic sustainability (yield and profit) positively while 
environmental (Orangutan and fire) and social (poverty and health service) aspect does not seem to be affected significantly by RSPO implementation [29]. This was in line with a study that revealed that habitat degradation, deforestation, fires, or other tree damages were still found in 40\% RSPOcertified concessions area even the tree removals were higher than the noncertified area [2]. In contrast, a study revealed that RSPO certification lowered deforestation in Indonesia's primary forest by $33 \%$ and RSPO also had no causal impact on forest loss in peatland or active fire detection rates [14].

\subsection{Export Decision}

Researchers investigated the US manufacturing firms' export decisions by testing the role of plant characteristics, entry costs, spillovers from neighboring exporters, and government export promotion expenditures [30]. They found that large (plant size proxied by total employment), productive, and multinational plants have higher probabilities of exporting. For entry cost which is drawn from the lagged export status (a proxy of sunk cost), researchers found that having exported last period increases the probability of exporting today by $39 \%$ whereas the benefit is reduced to $11.9 \%$ after two years. In the same year, a study found that firm size proxied by total sales is positively related to export probability in a majority of UK industries [31]. A similar relationship is also shown by product diversification and $R \& D$ expenditure.

Still from the same year, researchers studied that the bigger, older, and more productive firms are more likely to be exporters [32]. They added that foreignowned firms might be participating in export to utilize a production base to supply the foreign market. Similarly, a study argued that larger, older, foreign, and multinational enterprises are more likely to be exporters [33]. Also, export experience has the most positive impact on the firm's export participation decision, while the size is the greatest hindrance to internationalization. The government's subsidies are positively correlated with the export decision.

Another study found that firm size (proxied by sales), firm age, labor productivity, government assistance, foreign investment, municipal location, and skilled labor are significantly and positively affecting Thai manufacturing SMEs' export participation and performance [34]. It is supported by research that also found that the firm's size (reflected by the number of employees) and import value positively correlated with the possibilities of starting to export as well as the firm's productivity [35]. 


\subsection{Downstream Industry Development}

Awareness towards value-added of downstream products encourages government in palm oil producer countries to develop palm oil downstream' industry. It was observed that the high export volume of stearin, one of palm oil derivatives, indicates a significant overseas market opportunity [36]. This export volume can be described as the market demand for palm oil downstream products. The price of crude palm oil and its derivative as well as market demand for downstream products also seem to be leveraged to boost downstream industry development. An incentive for downstream products export is suggested to stimulate palm oil export in the form of its derivatives. A report also pledges revenue and market access as the benefits of RSPO implementation [25]. As the market access available, export in the form of palm oil downstream products will be more profitable for producer countries.

\section{Method}

This study employs secondary data acquired from the 2018 annual report of palm oil companies due to the availability matter. The sample consists of palm oil companies who are listed on Bursa Efek Indonesia and Bursa Malaysia. There are 18 companies from Indonesia and 41 companies from Malaysia. The sample is chosen through the purposive sampling method. The criteria of the sample are: (a) palm oil company that publish its annual report of the financial year 2018, (b) palm oil company that involves in the cultivation and processing of palm oil, (c) the annual report must release details about the CPO production. Following these criteria, one Indonesian and 15 Malaysian companies are eliminated and a Malaysian company also has to be excluded from the analysis because its palm oil-related business was sold to other company. This sample was then added with limited liabilities companies who are publishing their 2018 annual report on the website. With this re-organization, 18 Indonesian companies and 32 Malaysian companies are further being processed and analyzed.

As the RSPO certification becomes a non-contrary basic need in doing palm oil business nowadays, this study explores the impact of obtaining it on the possibility of firms' decision to export and develop downstream industry. Other variables, such as firm's size, firm's age, ownership structure, and export status are also employed since previous studies found it is essential in understanding export and downstream industry development. Details about variables is shown in Table 1. 
Table 1 Variable definition

\begin{tabular}{|c|c|}
\hline Variable & Definition \\
\hline Export decision & $\begin{array}{l}\text { Dichotomous dependent variable that takes value } 1 \text { if the firm } \\
\text { participate in international market (export) }\end{array}$ \\
\hline RSPO participation & Dummy variable that takes 1 if the firm holds RSPO certificate \\
\hline Firm's age & $\begin{array}{l}\text { Log of the number of years since the firm was } \\
\text { established/incorporated }\end{array}$ \\
\hline Firm's size & Log of the firm's CPO total production \\
\hline Ownership structure & $\begin{array}{l}\text { Dummy variable that takes value } 1 \text { if more than } 25 \% \text { of the firm } \\
\text { shares are foreign-owned }{ }^{1} \text {. }\end{array}$ \\
\hline Country dummy & $\begin{array}{l}\text { Dummy variable that takes } 1 \text { if the firm incorporates in } \\
\text { Indonesia and } 0 \text { if the firm incorporates in Malaysia }\end{array}$ \\
\hline $\begin{array}{l}\text { Downstream industry } \\
\text { development }\end{array}$ & $\begin{array}{l}\text { Dichotomous dependent variable that takes value } 1 \text { if the firm } \\
\text { derivate palm oil product }\end{array}$ \\
\hline Export status & Dummy variable that takes 1 if the firm is an exporter \\
\hline
\end{tabular}

The analysis process run with the help of SPSS 22. This study employs Binary Logistics Regression and based on two logits models as follows:

$\beta_{4} X_{4}+\beta_{5} X_{5}$

$$
\operatorname{logit} \mathrm{P}(\mathrm{X} 1)=\alpha+\beta_{1} X_{1}+\beta_{2} X_{2}+\beta_{3} X_{3}+
$$

Note:

$\mathrm{X} 1 \quad$ : Export decision

$X_{1} \quad$ : Categorical dummy RSPO participation

$X_{2} \quad$ : Firm's age

$X_{3} \quad$ : Firm's size

$X_{4} \quad$ : Categorical dummy ownership structure

$X_{5} \quad$ : Categorical country dummy variable

$\operatorname{logit} \mathrm{P}(\mathrm{X} 2)=\alpha+\beta_{1} X_{1}+\beta_{2} X_{2}+\beta_{3} X_{3}+\beta_{4} X_{4}+\beta_{5} X_{5}$

Note:

X2 : Downstream industry development

$X_{1} \quad$ : Categorical dummy variable RSPO participation

$X_{2} \quad$ : Categorical dummy variable export status

$X_{3} \quad$ : Firm's age

$X_{4} \quad$ : Firm's size

${ }^{1}$ Refers to [32] 
$X_{5} \quad$ : Categorical country dummy variable

\section{Result}

\subsection{Industry's Profile}

Palm oil is deliberately sold into the international market. According to Figure 1, the volume of CPO export is relatively small compared to its production volume in both countries. Moreover, in those four consecutive years, the trend of CPO export is dominantly decreasing. On average, $18.89 \%$ of Indonesia's CPO production is exported whereas Malaysia exports $20.09 \%$ of its CPO. This proportion shows that both countries are focusing on processing the $\mathrm{CPO}$ and/or prioritizing the domestic market. Recently, both countries are engaging in domestic downstream industry development. This agenda is brought to stabilize and strengthen the CPO market availability. By enabling domestic absorption, Indonesia and Malaysia can diminish some foreign currency-related risks as well as enjoying more revenue from high-value-added downstream products. This downstream master plan focuses on developing oleofood, oleochemical, and biofuels industry.

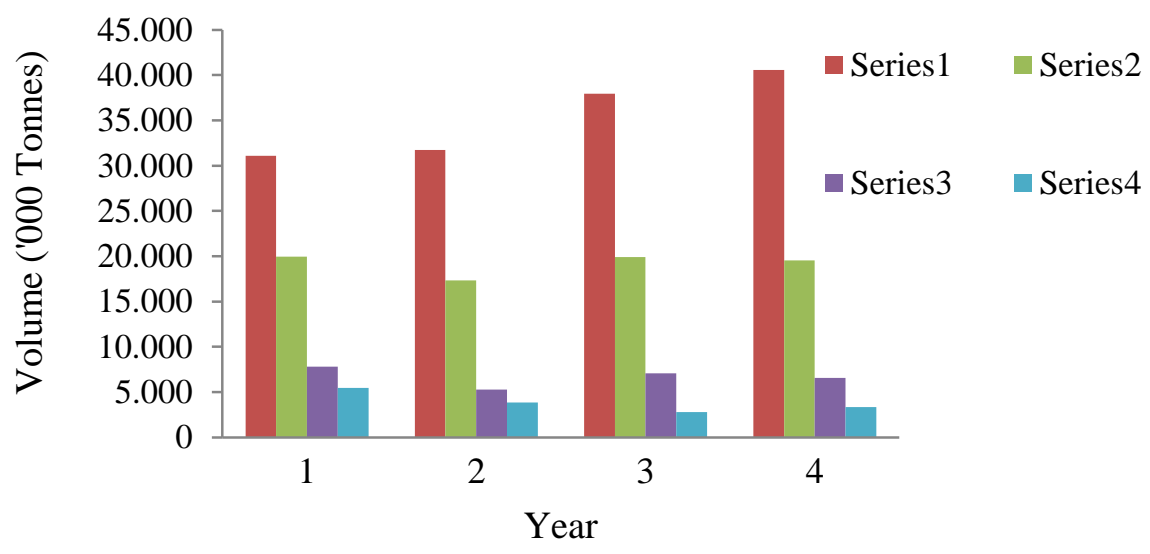

Fig 1 Production and export of crude palm oil 
Their seriousness in creating a domestic downstream industry is reflected by the number of palm oil processing facilities built in both countries. Figure 2 explains the percentage of processing facilities run by palm oil companies in this study. Based on this figure, both countries are mainly working on oleofood fields seen by the percentage of the refinery that proxy the manufacture of cooking oil, specialty oils and fats. Meanwhile, the palm oil mill becomes the most have facility as it produces the basic oil, namely crude palm oil. The nonproportionate portion between mill and kernel crushing-refinery facilities means that major palm oil companies in this study are selling their CPO to the nearest external kernel crusher and refinery. These two mid-to-downstream facilities are mostly owned by large companies because installing these facilities need lots of feedstock and funds that mid-sized company could not make it. Besides, palm oil companies also run by-product plants to further utilize the residue of palm oil production into fertilizer, animal feed, and electricity. Need to be underlined, by-product plant development was an intention in sustaining palm oil business activities.

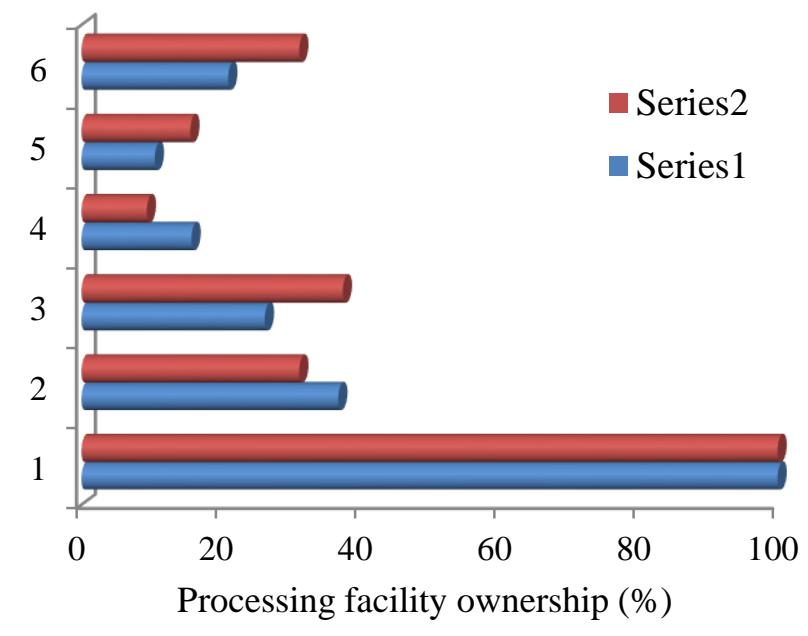

Fig 2 Percentage of processing facilities owned by firms

Development of downstream industry makes palm oil can be processed into heterogeneous products. The processed palm oil is then sold either to the domestic or international markets. Out of CPO produced by both countries as given in Figure 1, the remaining exported palm oil products are diversified into many derivatives of CPO and crude palm kernel oil (CPKO or PKO). Below is the details of palm oil products export in 2018 based on the Harmonized System (HS) Code 2017 (Table 2). The export of palm oil was dominated by Other than 
Crude Palm Oil which stands for refined and unrefined fraction CPO. In 2018, Indonesia and Malaysia serve mainly India, China, Pakistan, and the Netherlands oil market. These four destinations absorb $48.23 \%$ and $39.11 \%$ of total palm oil exported by Indonesia and Malaysia respectively.

Table 2 Palm oil product export by HS Code in $2018^{2}$

\begin{tabular}{|c|c|c|c|}
\hline \multirow{2}{*}{$\begin{array}{c}\text { HS } \\
\text { Code }\end{array}$} & \multirow{2}{*}{ Description } & \multicolumn{2}{|c|}{ Export volume (Tonnes) } \\
\hline & & Indonesia & Malaysia \\
\hline 120710 & Palm kernel & $55,290,086$ & $50,393,740$ \\
\hline 151110 & Crude palm oil and its fraction ${ }^{3}$ & $6,554,497,333$ & $3,341,772,210$ \\
\hline 151190 & Other than crude palm oil & $21,339,179,152$ & $10,499,612,890$ \\
\hline 151321 & Palm kernel oil and its fraction & $369,372,142$ & $340,380,282$ \\
\hline 151329 & Other than palm kernel oil & $1,403,530,469$ & $300,422,358$ \\
\hline 152000 & Glycerol, crude & $491,302,102$ & $59,246,449$ \\
\hline 230660 & Palm oil cake and other solid residues & $4,851,674,680$ & $2,411,038,460$ \\
\hline 290545 & Alcohols & $398,516,867$ & $381,284,326$ \\
\hline 382311 & Stearic acid & $645,052,482$ & $386,321,320$ \\
\hline 382312 & Oleic acid & $79,093,905$ & $107,189,492$ \\
\hline 382319 & $\begin{array}{l}\text { Other than stearic acid, oleic acid, or } \\
\text { tall oil fatty acid }\end{array}$ & $2,526,770,370$ & $1,741,252,950$ \\
\hline 382370 & Industry fatty alcohols & $543,268,206$ & $470,117,211$ \\
\hline 382600 & Biodiesel & $1,559,440,016$ & $529,857,118$ \\
\hline
\end{tabular}

In terms of the companies' profile studied in this research, Table 3 resumes it all. Most palm oil companies indeed well-experienced if seen by their age. They have been involved in the business for such a long time ago. Based on planted area and CPO volume, companies in both countries are classified as small-to-mid-sized companies. For sustainability certification, ISPO and MSPO become the most obtained in each country as it was counted as compulsory certification. Whereas for voluntary certification, RSPO remains favorable in both countries. From the annual report, Indonesian companies most active in agricultural-related business, such as crop production, agribusiness, forestry, and integrated farming as their side business while Malaysian companies are more focusing on service, investment, and property-related business. It was understandable since Indonesia is an agrarian country with a great source of natural resources.

\footnotetext{
${ }^{2}$ Sourced from UN Comtrade

${ }^{3}$ Stands for CPO in Figure 1
} 
Table 3 Palm oil company profile

\begin{tabular}{|c|c|c|}
\hline \multirow{2}{*}{ Characteristics } & \multicolumn{2}{|c|}{ Percentage } \\
\hline & Indonesia & Malaysia \\
\hline \multicolumn{3}{|l|}{ Age } \\
\hline$<20$ years old & 22.22 & 12.5 \\
\hline $20-50$ years old & 55.56 & 43.75 \\
\hline$>50$ years old & 22.22 & 43.75 \\
\hline \multicolumn{3}{|l|}{ Total planted area (Ha) } \\
\hline$<100000$ & 55.56 & 84.38 \\
\hline $100000-200000$ & 27.78 & 6.25 \\
\hline$>200000$ & 16.67 & 9.38 \\
\hline \multicolumn{3}{|l|}{ CPO Produced (MT) } \\
\hline$<500000$ & 77.78 & 84.38 \\
\hline $500000-1000000$ & 11.11 & 9.38 \\
\hline$>1000000$ & 11.11 & 6.25 \\
\hline \multicolumn{3}{|l|}{ Certification obtained } \\
\hline RSPO & 44.44 & 40.63 \\
\hline ISPO/MSPO & 88.89 & 68.75 \\
\hline ISCC & 16.67 & 31.25 \\
\hline \multicolumn{3}{|l|}{ Ownership structure } \\
\hline Local company & 77.78 & 84.38 \\
\hline Foreign-owned company & 22.22 & 15.63 \\
\hline Exporters & 44.44 & 40.63 \\
\hline Downstream developer & 44.44 & 38.71 \\
\hline
\end{tabular}

\subsection{Export Decision}

The model proposed was able to correctly classify $81 \%$ of those who decide to export and $83 \%$ of those who did not, with an overall success rate of $82 \%$. The significance of the Omnibus Test is under 0.05 and based on the Nagelkerke $\mathrm{R}$ square, all variables in the model simultaneously affect export decision $58.7 \%$, the remainings are explained by other variables. Hosmer and Lemeshow Test amounted to 2.243 significance value 0.973 which indicates that this model is fit. Besides, employing these five variables, namely RSPO participation, Firm's age, Firm's size, Ownership structure, and Country found to be significantly better than the model with the only intercept in it. It showed by the decrease of -2 Log-Likelihood from 68.029 to 39.354. Also, the model's ability in predicting events correctly increased from $58 \%$ to $82 \%$.

Table 4 shows the logistic regression coefficient, Wald test, and the odds ratio for each of the predictors. Employing a 5\% criterion of statistical significance, only RSPO participation found to significantly influence the company's decision to export. The model predicts that the odds of deciding to export are 13.368 higher for RSPO-certified companies than those who did not. 
It indicates that RSPO certification holders eager to optimally make use of it to freely supply any countries with their sustainable-guaranteed palm oil products. Furthermore, being RSPO-certified indeed creates and increases the firm's good image and reputation in terms of sustainability [20] [37]. So, it will be a great means to stay competitive in a fluctuating international market.

Additionally, the Firm's size was found to be significant at the $10 \%$ significance level. It shows that larger firms are more likely to be an exporter. By the odds ratio, it is predicted that the decision to export is one times higher for a firm who is one metric ton (MT) greater in CPO production than the compared firm. Likewise, a research found an empirical link between certification, export performance, and the firm's size of textile and agro-food firms in Pakistan [38]. It is said that ISO 9000-certified firms tend to share higher export sales and are categorized as large firms.

Regarding RSPO participation, although RSPO is seen as somewhat unfair and not as beneficial as expected for producer countries [39], its positive relationship towards export decision might be influenced by the size of the corresponding firm. A large firm must be supported by abundant resources. Efficiency and efficacy are an ingrained culture of doing business in such firms. Therefore, the cost of obtaining RSPO certification would not bring a meaningful effect on the firm's cash flow since its large resources are optimally utilized to fulfill a more profitable international market. From a large firm's perception, this certification is considered as a complement document to extend their market share. Besides, being complied with RSPO standards will also bring in premium price of certified sustainable palm oil which becomes a lucrative incentive for all palm oil supply chain actors.

Surprisingly, this research found that age and ownership structure was not significantly affected the export decision. It shows that the palm oil global market is widely open and fairly competitive since the firm's age and ownership status did not count as a barrier. It could be caused by the massive support of the government towards palm products export without taking the firm's age or experience into account. It was understandable since palm oil products become an important source of foreign exchange income. In terms of ownership structure and country, foreign-owned firms and Malaysian firms are more likely to be exporters although these two variables are insignificant toward the export decision. 
Table 4 Variables affecting export decision

\begin{tabular}{llcccr}
\hline & B & Wald & Sig. & Exp(B) \\
\hline Step 1 & RSPO participation (1) & 2.593 & 9.554 & $0.002^{* *}$ & 13.368 \\
& Firm's age & -0.011 & 0.596 & 0.440 & 0.989 \\
& Firm's size & 0.000 & 3.642 & $0.056^{*}$ & 1.000 \\
Ownership structure (1) & 0.083 & 0.007 & 0.931 & 1.086 \\
Country (1) & -1.014 & 1.014 & 0.314 & 0.363 \\
Constant & -1.839 & 3.452 & 0.063 & 0.159 \\
\hline
\end{tabular}

"significant at the $10 \%$ level

** significant at the $5 \%$ level

\subsection{Downstream Industry Development}

The Omnibus test result shows that $P$-value is $<0.05$ and the model's Chisquare is greater than table Chi-square $(\mathrm{df}=5 ; 0.05)(46.544>11.070)$. Refer to Nagelkerke R square, all variables in the model simultaneously affect export decision $81.5 \%$ and the remainings are explained by other variables. Hosmer and Lemeshow Test amounted to 4.983 with a significance value of 0.759 which indicates that this model is fit. Moreover, adding these five variables, namely RSPO participation, Firm's age, Firm's size, Export status, and Country found to be significantly better than the model with the only intercept in it. It showed by the decrease of -2 Log-Likelihood from 68.029 to 21.485. Also, the model's ability in predicting events correctly increased from $58 \%$ to $92 \%$.

The following Table 5 shows the logistic regression coefficient, Wald test, and odds ratio for each of the predictors. Employing a 5\% criterion of statistical significance, only Export status was found to significantly influence downstream development. The model predicts that the odds of deciding to develop are 197.291 higher for exporters than those who are not. Logically if the feedstock supplies were stagnant, an increased rate of CPO export will automatically lower the supply for the domestic downstream industry. Based on this theory, the export will hinder downstream industry development. But surprisingly, this study found the opposite. It reveals that the export market generates global demand which stimulates downstream development. Both countries started to restrict export in the form of raw materials and turned it into more added value downstream products.

The idea of this shifting trend was to come up to make use of the geographical advantages to produce more palm oil [40]. Also, it is stated that a variety of downstream products were meant to fulfill the request of global 
consumers [41]. This is in line with the commitment of Indonesia and Malaysia, making palm oil downstream become the superior product exported [40] [41]. This result then supports previous studies that claimed that exporters are enjoying added value by selling palm oil downstream. In addition, the export tariffs decreased as the raw materials were processed further [42]. By developing palm oil downstream, exporters will engage in new market opportunities.

Meanwhile, at a $10 \%$ significance level, the Firm's size plays a significant role in influencing the downstream decision. Likewise export decision, it is predicted that the decision to develop downstream industry is one times higher for a firm who is one metric ton (MT) greater in CPO production than the compared firm. The sufficient amount of CPO indeed securing a sustainable supply of feedstock from upstream to the downstream production activities [41]. As mentioned before, Indonesia and Malaysia were long known as the largest palm oil producers worldwide. The ability of the firm to produce more CPO should be utilized to build a strong in-house downstream supply and value chain. The increasing demand from domestic downstream industries would affect the competitiveness of CPO price and therefore would avoid meaningless added value from downstream products [43].

Surprisingly, companies who are not RSPO-certified found attracted more in the downstream industry although this result turned out insignificant. A research finding argues that RSPO Principles and Criteria, the rule of managing palm oil plantation, is more focusing on the upstream [44]. There are no specific clauses on how to process palm oil sustainably. The absence of proper and personalized standards on doing sustainable downstream activities could be the main reason which provides this research result. Additionally, this negative relationship is probably caused by the low uptake of certified palm oil or the less attractive premium price of certified products. The lack of incentives for 'the sacrifices' done by the upstream sector has made the sustainable palm oil market activity sluggish. As RSPO was a means to sell palm oil worldwide, the absence of RSPO then resulted in the rise of awareness and stimulation to utilized oil palm domestically.

Malaysia once again was found to be more likely to develop the downstream industry. They had become export-oriented since a long time ago when Indonesia still focused on import-substitution strategy. Unlike previous analysis, the firm's age is insignificant but has a positive sign. It means that older firms are predicted to develop downstream more than the younger ones. As discussed above, the downstream industry's activities are more complex, costly, and various so that well-experienced firms become the basic and general requirements in this industry. 
Table 5 Variables affecting downstream industry development

\begin{tabular}{llcllc}
\hline & B & Wald & Sig. & Exp(B) \\
\hline Step 1 & RSPO participation (1) & -0.482 & 0.120 & 0.730 & 0.618 \\
& Firm's age & 0.012 & 0.380 & 0.538 & 1.012 \\
& Firm's size & 0.000 & 2.715 & $0.099^{*}$ & 1.000 \\
& Export status (1) & 5.285 & 8.766 & $0.003^{* *}$ & 197.291 \\
& Country (1) & -1.788 & 1.068 & 0.301 & 0.167 \\
& Constant & -4.997 & 5.585 & 0.018 & 0.007 \\
\hline
\end{tabular}

* significant at the $10 \%$ level

** significant at the $5 \%$ level

\section{Conclusion}

Indonesia and Malaysia as the world's largest palm oil suppliers revealed to share a similar profile in common. But it can be inferred from this study that Malaysian companies are more export-oriented seen by the percentage of downstream facilities. Meanwhile, Indonesia seems to start focusing on the downstream industry showed by the number of more basic downstream facilities. In terms of the export decision, firms who are large, producing more $\mathrm{CPO}$, and already obtain RSPO certification are more likely to be exporters significantly. Meanwhile, the possibility to develop downstream industry is higher for those who export their palm oil and run large-sized firms. Regarding sustainability commitment, this research found that only export decisions are influenced by RSPO participation. The decision to develop downstream industries was driven by the eagerness to utilize the large resources optimally. Since this industry could create added value and higher profit, both governments should better facilitate palm oil companies who are willing to build downstream facilities or spreading the spillover effect so that the non-exporters are interested to develop the downstream industry as well. It also can be done by increasing the domestic demand for processed palm oil, such as biodiesel since both countries are densely populated. 


\section{References}

1. Khatun R, Reza MIH, Moniruzzaman M, Yaakob Z. Sustainable oil palm industry: The possibilities. Renewable and Sustainable Energy Reviews. 2017;76(March):60819.

2. Cazzolla Gatti R, Liang J, Velichevskaya A, Zhou M. Sustainable palm oil may not be so sustainable. Science of the Total Environment [Internet]. 2019;652:48-51.

Available from: https://doi.org/10.1016/j.scitotenv.2018.10.222

3. Basiron Y, Weng CK. The Oil Palm and its Sustainability. Journal of Oil Palm Research. 2004;16(1):1-10.

4. Acosta P, Curt MD. Understanding the expansion of oil palm cultivation: A case-study in Papua. Journal of Cleaner Production [Internet]. 2019;219:199-216. Available from: https://doi.org/10.1016/j.jclepro.2019.02.029

5. Tan YD, Lim JS. Feasibility of palm oil mill effluent elimination towards sustainable Malaysian palm oil industry. Renewable and Sustainable Energy Reviews [Internet]. 2019;111(May):507-22. Available from: https://doi.org/10.1016/j.rser.2019.05.043

6. P. P, S. G, A. D, H. K, B. O. The palm oil global value chain: Implications for economic growth and social and environmental sustainability. The palm oil global value chain: Implications for economic growth and social and environmental sustainability. 2017;

7. Santika T, Wilson KA, Budiharta S, Law EA, Poh TM, Ancrenaz M, et al. Does oil palm agriculture help alleviate poverty? A multidimensional counterfactual assessment of oil palm development in Indonesia. World Development. 2019;120:105-17.

8. Austin KG, Schwantes A, Gu Y, Kasibhatla PS. What causes deforestation in Indonesia? Environmental Research Letters. 2019;14(2).

9. Aja A, Oseghale S, Mohamed A. Status Evaluation of Palm Oil Waste Management Sustainability in Malaysia. OIDA International Journal of Sustainable Development. 2017;10(12):41-8.

10. Papilo P, Marimin, Hambali E, Sitanggang IS. Sustainability index assessment of palm oil-based bioenergy in Indonesia. Journal of Cleaner Production. 2018;196:80820 .

11. Corciolani M, Gistri G, Pace S. Legitimacy struggles in palm oil controversies: An institutional perspective. Journal of Cleaner Production [Internet]. 2019;212:1117-31. Available from: https://doi.org/10.1016/j.jclepro.2018.12.103

12. Oil P, Popular IA, Ingredient BC, Representative T. The truth about palm oil. 1991;(June):1-8.

13. Barthel M, Jennings S, Schreiber W, Sheane R, Royston S, Llp K, et al. Study on the environmental impact of palm oil consumption and on existing sustainability standards [Internet]. LMC International Ltd. 2018. 1-131. Available from: http://ec.europa.eu/environment/forests/pdf/palm_oil_study_kh0218208enn_new.pdf

14. Carlson KM, Heilmayr R, Gibbs HK, Noojipady P, Burns DN, Morton DC, et al. Effect of oil palm sustainability certification on deforestation and fire in Indonesia. Proceedings of the National Academy of Sciences of the United States of America. 2018;115(1):121-6.

15. Glasbergen P. Smallholders do not Eat Certificates. Ecological Economics. 2018;147(February):243-52. 
16. Oosterveer P, Adjei BE, Vellema S, Slingerland M. Global sustainability standards and food security: Exploring unintended effects of voluntary certification in palm oil. Global Food Security [Internet]. 2014;3(3-4):220-6. Available from: http://dx.doi.org/10.1016/j.gfs.2014.09.006

17. Tey YS, Brindal M, Darham S, Sidique SFA, Djama M. Early mover advantage in Roundtable on Sustainable Palm Oil certification: A panel evidence of plantation companies. Journal of Cleaner Production. 2020;252.

18. Oosterveer P. Promoting sustainable palm oil: Viewed from a global networks and flows perspective. Journal of Cleaner Production. 2015;107:146-53.

19. Access O. Journal of Oil Palm , Environment \& Health THE BURDEN OF RSPO CERTIFICATION COSTS ON MALAYSIAN PALM OIL INDUSTRY AND NATIONAL ECONOMY Yusof Basiron *, Foong-Kheong Yew. 2016;19-27.

20. Schouten G, Glasbergen P. Creating legitimacy in global private governance : The case of the Roundtable on Sustainable Palm Oil. 2011;70:1891-9.

21. OECD - FAO Agricultural Outlook 2018 - 2027. 2018;

22. Tay MY, Rahman AA, Aziz YA, Sidek S. A Review on Drivers and Barriers towards Sustainable Supply Chain Practices. International Journal of Social Science and Humanity. 2015;5(10):892-7.

23. Abd Rahman A, Ho JA, Rusli KA. Pressures, green supply chain management practices and performance of ISO 14001 certified manufacturers in Malaysia. International Journal of Economics and Management. 2014;8(Specialissue):1-24.

24. Mohiuddin M, al Mamun A, Syed FA, Masud MM, Su Z. Environmental knowledge, awareness, and business school students' intentions to purchase green vehicles in emerging countries. Sustainability (Switzerland). 2018;10(5).

25. Levin J. Analysis of Incremental Financial Costs and Benefits Profitability and Sustainability in Palm Oil Production. 2012;

26. Shahida S, Hafizuddin-Syah BAM, Fuad SH. The effect of sustainability certification for export on operational profitability of Malaysian palm oil companies. Jurnal Ekonomi Malaysia. 2018;52(2).

27. Hafizuddin-Syah BAM, Shahida S, Fuad SH. Sustainability certifications and financial profitability: An analysis on palm oil companies in Malaysia. Jurnal Pengurusan. 2018;54(2018):143-54.

28. Mansor N, Wan Abdullah WA, Asniati B, Hassan Syukri AF. Palm Oil Sustainability Certification and Firm Performance: Is There a Conflict Between RSPO and MSPO? 2016; Available from: www.iafor.org

29. Morgans CL, Meijaard E, Santika T, Law E, Budiharta S, Ancrenaz M, et al. Evaluating the effectiveness of palm oil certification in delivering multiple sustainability objectives. Environmental Research Letters. 2018;13(6).

30. Bernard AB, Wagner J. Export Entry and Exit by German Firms. Weltwirtschaftliches Archiv. 2001;137(1):105-23.

31. Gourlay AR, Seaton J. Explaining the decision to export: Evidence from UK firms. Applied Economics Letters. 2004;11(3):153-8.

32. Manez JA, Rochina ME, Sanchis JA. The decision to export: A panel data analysis for Spanish manufacturing. Applied Economics Letters. 2004;11(11):669-73.

33. Part RC. 기사 (Article) 와 안내문 (Information) [. The Eletronic Library. 2010;34(1):1-5. 
34. Amornkitvikai Y, Harvie C, Charoenrat T. Factors affecting the export participation and performance of Thai manufacturing small and medium sized enterprises (SMEs). 57th International Council for Small Business. 2012;1-35.

35. Hu C, Tan Y. Export spillovers and export performance in China. China Economic Review [Internet]. 2016;41:75-89. Available from: http://dx.doi.org/10.1016/j.chieco.2016.08.008

36. Rifai N, Syaukat Y, Siregar H, Sa'id EG. The Development and Prospect of Indonesian Palm Oil Industry and Its Derivative Products. IOSR Journal of Economics and Finance. 2014;4(5):27-39.

37. el Ammari Y, Harmouzi A, Chaouch A, Hadiri H, el Ammari S. Relationship between certification and export in Moroccan food industry. Der Pharmacia Lettre. 2015;7(1):14-20.

38. Masakure O, Henson S, Cranfield J. Standards and export performance in developing countries: Evidence from Pakistan. Journal of International Trade and Economic Development. 2009;18(3):395-419.

39. Wijaya A. The response of the government to the RSPO: towards a more sustainable palm oil?. In: Griffith M, Warsito T, Bin Ahmad Z, Hubacek K, Trinidad D, Weiss J, Nurmandi A, Choi JW, Kim SY, Purnomo EP et al, editor. International Conference on Social Politics; 2016 Jan 26-28; Yogyakarta, Indonesia. Yogyakarta (ID): Jusuf Kalla School of Government; 2016. p 801-812.

40. Arsyad M, Amiruddin A, Suharno S, Jahroh S. Competitiveness of Palm Oil Products in International Trade: An Analysis between Indonesia and Malaysia. Caraka Tani: Journal of Sustainable Agriculture. 2020;35(2):157.

41. Alang Mahat Suhaila. The Palm Oil Industry From The Perspective of Sustainable Development: A Case Study of Malaysian Palm Oil Industry. Ritsumeikan Asia Pacific University Japan [Internet]. 2012;(September):14. Available from: http://rcube.ritsumei.ac.jp/bitstream/10367/4738/1/51210600.pdf

42. Fung KC, Korinek J. Economics of Export Restrictions As Applied To Industrial Raw Materials. OECD Trade Policy Paper. 2013;155(2012):1-33.

43. Novindra N, Sinaga BM, Hartoyo S, Erwidodo E. Impact of Increasing in Production Capacity of CPO Downstream Industries on Competitiveness and Welfare of Oil Palm Farmers in Indoneisa. International Journal of Oil Palm. 2019;2(2):61-73.

44. Pichler M. "People, Planet \& Profit": Consumer-Oriented Hegemony and Power Relations in Palm Oil and Agrofuel Certification. Journal of Environment and Development. 2013;22(4):370-90. 